\title{
EFEKTIFITAS PENAMBAHAN ASAM AMINO PADA PAKAN UNTUK PERTUMBUHAN IKAN SIDAT, Anguilla bicolor (McCelland, 1844)
}

\author{
Ricky Hadi Pratama*1, Tarsim, dan Indra Gumay Yudha*2
}

\begin{abstract}
Eel is one of the fisheries commodity that have not been rearing widelyin Indonesia. Constraint that occured in rearing eel is slow growth. A way to accelerate eel growth isfeeding with enrichment by using an amino acids. An amino acids can be used directly by eel for cell growth and the formation of body tissue. An amino acid that is used from the stingrays are not utilized by people because it has no economic value to production activities. This research was aimed to study the growth rate of eel whichis fed with enrichment of an amino acids derived from stingray extract. The method in this research used completely randomized design (CRD) with 3 treatments and 3 replications. The measure of eel that usedare $26-28 \mathrm{~cm}$, the average weight is 28 grams and an amino acids dosage that used are $0 \mathrm{ml}, 0.5 \mathrm{ml}$ and $1 \mathrm{ml}$. It use FR 3\% which is given at night to support the characteristic of eel that is nocturnal (active at night). The analyze result from the parameters that have been observed, there is not a significant effect $(P>0.05)$ and the fed with enrichment by using an amino acids with the dosage used hasn't been able to be utilized as fish feed mixture to increase growth rate.
\end{abstract}

Keywords : eel fish, feed, slow growth, stingray, amino acid

\section{Pendahuluan}

Ikan sidat (Anguilla bicolor) adalah salah satu komoditas perikanan yang belum banyak dibudidayakan di Indonesia.Terdapat 7 spesies ikan sidat di Indonesia dari 16 spesies yang tersebar di dunia.Ikan sidat termasuk komoditas ekspor perikanan yang memiliki nilai jual tinggi hingga mencapai US\$ 5070/kg.Oleh sebab itu, hal ini dapat menjadi kesempatan bagi Indonesia untuk mengembangkan ikan sidat sebagai salah satu komoditas ekspor untuk beberapa negara di dunia.

Kendala dalam budidaya sidat adalah pertumbuhannya sangat lambat. Sidat merupakan ikan karnivor yang membutuhkan protein tinggi lebih dari 45\% (Affandi, 2005). Beberapa penelitian telah dilakukan untuk menunjang pertumbuhan sidat, namun hasilnya belum mampu

\footnotetext{
${ }^{1}$ E-mail : rickyhadip@gmail.com

${ }^{2} J u r u s a n$ Perikanan dan Kelautan, Fakultas Pertanian, Universitas Lampung

Jl. Prof. S. Brodjonegoro No.1 Gedong Meneng Bandar Lampung, 35145
} 
meningkatkan laju pertumbuhan ikan sidat. Oleh karena itu, perlu dicari alternatif pengkaya lain sehingga bisa digunakan untuk meningkatkan laju pertumbuhan sidat.

Alternatif pengkaya lain yang dapat digunakan adalah kandungan asam amino yang terdapat dalam tubuh ikan pari bubur. Menurut Mardiah (2008), ikan pari bubur memiliki 16 kandungan asam amino yaitu alanin, arginin, asam aspartat, cistin, asam glutamat, glisin, histidin, isoleusin, leusin, lisin, methoinin, phenilalanin, prolinserin, theonin, tirosin dan valin. Asam amino diperlukan secara terus menerus oleh ikan melalui protein yang terkandung di dalam pakan yang digunakan untuk pertumbuhan sel dan pembentukan jaringan tubuhnya (Buwono, 2000). Oleh karena itu, pengkayaan dengan menggunakan ekstrak ikan pari yang terbaik diharapkan dapat mempercepat laju pertumbuhan sidat.

Penelitian ini bertujuan untuk mempelajari laju pertumbuhan ikan sidat yang diberi pakan dengan pengkayaan asam amino yang berasal dari ekstrak ikan pari.

\section{Metode}

Penelitian ini dilakukan pada bulan November 2017 sampai Januari 2018 di Laboratorium Budidaya Perikanan, Jurusan Perikanan dan Kelautan, Fakultas Pertanian, Universitas Lampung. Adapun uji proksimat pakan dilakukan di Laboratoritum Teknologi Hasil Pertanian Politeknik Negeri Lampung dan analisis uji kandungan asam amino dilakukan di PT. Saraswanti Indo Genetech. Penelitian ini menggunakan rancangan acak lengkap (RAL) dengan 3 perlakuan A $(0 \mathrm{ml}$ asam amino $+5 \mathrm{ml} \mathrm{NaCl})$. B $(0,5 \mathrm{ml}$ asam amino $+5 \mathrm{ml} \mathrm{NaCl})$ dan $\mathrm{C}(1 \mathrm{ml}$ asam amino $+5 \mathrm{ml} \mathrm{NaCl})$ dan 3 kali ulangan.

\section{Persiapan wadah pemeliharaan}

Penelitian ini menggunakan akuarium sebanyak 9 unit berukuran $60 \times 40 \times 30 \mathrm{~cm}^{3}$ untuk wadah pemeliharaan ikan sidat. Sebelum digunakan, akuarium dibersihkan terlebih dahulu dan dikeringkan. Setelah itu akuarium disusun berdasarkan pengacakan untuk masing-masing perlakuan. Akuarium diisi air sebanyak 301 dan dilengkapi aerasi untuk menjaga agar oksigen dalam wadah pemeliharaan tetap optimum. Bagian atas akuarium diberi waring dan ditutup styrofoam agar ikan sidat dalam wadah pemeliharaan tidak keluar.

\section{Ikan Sidat}

Ikan sidat yang digunakan berukuran $26-28 \mathrm{~cm}$ dengan berat rata-rata $28 \mathrm{~g}$, dipelihara dalam wadah pemeliharaan dengan kepadatan 5 ekor/wadah pemeliharaan. Setelah itu dilakukan adaptasi didalam akuarium selama 20 hari, pakan yang diberikan selama masa adaptasi berupa pakan komersil yang mengandung protein $34 \%$.

\section{Pakan}

Proses pengayaan pakan dengan penambahan asam amino yang berasal dari ekstrak ikan pari dilakukan dengan metode spray yang disemprotkan langsung pada pakan yang telah ditimbang berdasarkan FR $3 \%$ dari bobot ikan sidat pada setiap akuarium. Metode spray dilakukan dengan menambahkan $0,5 \mathrm{ml}$ dan 1 
$\mathrm{ml}$ asam amino yang berasal dari ekstrak ikan pari dan menambahkan larutan fisiologis $5 \mathrm{ml}$ pada setiap perlakuan sebagai bahan pelarutnya. Pakan yang telah disemprotkan dengan ekstrak ikan pari dikeringkan di bawah sinar matahari.

\section{Pelaksanaan penelitian}

Ikan sidat dipelihara selama 60 hari dan diberi pakan komersil yang telah dilakukan pengayaan dengan menggunakan asam amino dari ekstrak ikan pari. Pemberian pakan dilakukan menggunakan feeding rate (FR) $3 \%$ pada malam hari yang dimulai pada pukul 18.00 - 24.00 WIB. Untuk menjaga agar kualitas air media pemeliharaan tetap baik, maka dilakukan penyiponan setiap pagi. Kegiatan sampling pertumbuhan ikan sidat dilakukan selama 20 hari dalam masa pemeliharaan.

Uji proksimat pakan dan tubuh ikan sidat

Pelaksanaan uji proksimat pakan dan tubuh ikan sidat menggunakan prosedur menurut Takeuchi (1988). Pengujian ini dilakukan untuk mengetahui kadar protein, lemak, karbohidrat, air, abu dan serat kasar yang terdapat pada pakan dan tubuh sidat. Uji kadar protein menggunakan metode semi murni Kjedahl sedangkan lemak menggunakan metode ether ekstraksi Soxhlet.

\section{Analisis statistik}

Analisis data dilakukan secara deskriptif dan kuantitatif. Data yang diperoleh dari pengamatan akan ditabulasi dan dianalisis menggunakan program excel 2013 dan SPSS v.22. Data uji proksimat pakan dan kualitas air akan dianalisis secara deskriptif. Untuk data penelitian seperti laju pertumbuhan harian, efisiensi pakan, retensi protein, dan jumlah konsumsi pakan akan dianalisis menggunakan sidik ragam dengan selang kepercayaan 95\%. Jika data yang diperoleh menunjukkan hasil yang berbeda nyata, maka akan dilanjutkan dengan uji Tukey.

\section{Hasil dan Pembahasan}

$\begin{array}{llr}\text { Pakan yang } & \text { diberikan } & \text { sangat } \\ \text { erat kaitannya } & \text { dengan } & \text { proses } \\ \text { pertumbuhan, } & \text { ikan } & \text { dapat }\end{array}$
memanfaatkan pakan dengan baik apalagi kebutuhan nutrisi dalam pakan sesuai untuk pertumbuhannya. Energi yang terkandung di dalam pakan sangat diperlukan untuk proses metabolisme, perawatan tubuh (maintenance), aktifitas fisik, pertumbuhan dan reproduksi (NRC, 1993). Pakan sidat yang diberi penambahan asam amino yang berbeda setelah dilakukan analisis proksimat (Tabel 1), menghasilkan kandungan nutrisi yang relativ sama terutama kandungan proteinnya. Kandungan protein pada pakan dengan penambahan asam amino 0,5 $\mathrm{ml}$ dan $1 \mathrm{ml}$ menghasilkan kandungan protein $32 \%$.

Cheng et al (2013) menyatakan bahwa kebutuhan protein ikan sidat (A. mormotrata) pada ukuran 2,29 g adalah $50 \%$ dan pada saat ukurannya 21,97 g kebutuhan protein yang digunakan adalah $45 \%$. Pada penelitian ini, ikan sidat (A. bicolor) dengan ukuran $28 \mathrm{~g}$ mengalami pertumbuhan pada kandungan protein yang lebih rendah yaitu $32 \%$. Hal ini 
menunjukkan bahwa protein yang dihasilkan pada pakan telah memenuhi kebutuhan energi tubuh ikan sidat sehingga kelebihannya dapat digunakan untuk proses pertumbuhan. Kebutuhan protein akan menurun dengan meningkatkan bobot dan usia ikan (Abdel-Tawwab et al., 2010).

Hasil analisis ragam menunjukkan bahwa laju pertumbuhan spesifik, efesiensi pakan, jumlah konsumsi pakan, retensi protein, dan tingkat kelulushidupan yang dihasilkan tidak memberikan pengaruh nyata antar perlakuan $\quad(p>0,05)$ Beberapa parameter yang diamati dapat dilihat pada Tabel 2.

Kualitas air selama pemeliharaan (Tabel 3) tergolong optimal pada parameter suhu dan DO, pada paramater $\mathrm{pH}$ nilai yang didapat tidak tergolong optimal. Nilai $\mathrm{pH}$ yang terlalu rendah dapat menyebabkan nafsu makan ikan menurun. Hal ini disebabkan produksi enzim pencernaan yang rendah yang menimbulkan ikan mengalami kematian (Riana, 2016).

Tabel 1. Hasil uji proksimat pakan

\begin{tabular}{lccc}
\hline \multirow{2}{*}{ Kandungan (\%) } & A & B & Cakan Perlakuan \\
\cline { 2 - 4 } & 13,87 & 14,06 & 16,08 \\
\hline Kadar air & 31,91 & 32,53 & 32,84 \\
Protein & 3,396 & 3,333 & 3,119 \\
Lemak & 8,764 & 8,892 & 8,690 \\
Kadar abu & 1,523 & 1,910 & 2,372 \\
Serat kasar & 40,52 & 39,25 & 36,89 \\
Karbohidrat & 3.757 & 3.737 & 3.637 \\
\hline GE (kkal/g)* & \multicolumn{3}{c}{$*$ GE (Gross energy) adalah energi yang terkandung dalam pakan berdasarkan nilai ekuivalen } \\
untuk karbohidrat 4,1 kkal/g, lemak 9,4 kkal/g, dan protein 5,6 kkal/g.
\end{tabular}

Tabel 2. Hasil laju pertumbuhan spesifik, jumlah konsumsi pakan, efesiensi pakan, retensi protein, dan tingkat kelulushidupan ikan sidat.

\begin{tabular}{lccc}
\hline \multirow{2}{*}{ Parameter Penelitian } & \multicolumn{3}{c}{ Penambahan Asam Amino dari Ekstrak Ikan } \\
& \multicolumn{3}{c}{ Pari } \\
\cline { 2 - 4 } & $4,98 \pm 0,71^{\mathrm{a}}$ & $5,39 \pm 0,28^{\mathrm{a}}$ & $\mathbf{C}(\mathbf{0 , 5} \mathbf{~ m l})$ \\
\hline $\begin{array}{l}\text { Laju pertumbuhan } \\
\text { spesifik (\%) }\end{array}$ & & & \\
Jumlah konsumsi pakan & $147,9 \pm 85,5^{\mathrm{a}}$ & $171,3 \pm 83,3^{\mathrm{a}}$ & $151,7 \pm 51,9^{\mathrm{a}}$ \\
(gram) & & & \\
Efesiensi pakan (\%) & $64,9 \pm 13,32^{\mathrm{a}}$ & $83,1 \pm 13,51^{\mathrm{a}}$ & $81,6 \pm 12,27^{\mathrm{a}}$ \\
Retensi protein (\%) & $17,04 \pm 7,87^{\mathrm{a}}$ & $27,92 \pm 12,53^{\mathrm{a}}$ & $25,84 \pm 7,32^{\mathrm{a}}$ \\
$\begin{array}{l}\text { Tingkat kelangsungan } \\
\text { hidup (\%) }\end{array}$ & $66,7 \pm 11,5^{\mathrm{a}}$ & $80 \pm 20^{\mathrm{a}}$ & $80 \pm 20^{\mathrm{a}}$ \\
\hline
\end{tabular}


Tabel 3. Data kualitas air selama pemeliharaan

\begin{tabular}{lcc}
\multicolumn{1}{c}{ Parameter } & Kisaran & Baku Mutu* \\
\hline Suhu $\left({ }^{\circ} \mathrm{C}\right)$ & $25-26$ & $25-30$ \\
pH & 6 & $6,5-8$ \\
DO $(\mathrm{mg} / \mathrm{l})$ & $5-6$ & $1-10$ \\
\hline
\end{tabular}

*Sumber :Sholeh (2006)

Tabel 4. Perbandingan kandungan asam amino (mg) pakan uji dengan asam amino yang berasal dari ekstrak ikan pari

\begin{tabular}{|c|c|c|c|c|}
\hline \multirow{3}{*}{$\begin{array}{c}\text { Asam } \\
\text { amino }\end{array}$} & \multirow{3}{*}{$\begin{array}{c}\text { Kebutuhan asam } \\
\text { amino (\% dari } \\
\text { Protein)*/5 g } \\
\text { pakan }\end{array}$} & \multicolumn{3}{|c|}{ Kandungan asam amino (mg) } \\
\hline & & \multirow{2}{*}{ Pakan uji** } & \multicolumn{2}{|c|}{ Ekstrak ikan pari*** } \\
\hline & & & $0,5 \mathrm{ml}$ & $1 \mathrm{ml}$ \\
\hline Arginin & $4,5(76,50)$ & $108,66(+)$ & 0,075 & 0,150 \\
\hline Fenilalanin & $5,8(98,60)$ & $93,14(-)$ & 0,079 & 0,159 \\
\hline Histidin & $2,1(35,70)$ & $41,90(+)$ & 0,061 & 0,122 \\
\hline Isoleusin & $4,0(68,00)$ & $74,72(+)$ & 0,149 & 0,299 \\
\hline Leusin & $5,3(90,10)$ & $136,11(+)$ & 0,193 & 0,386 \\
\hline Lisin & $5,3(90,10)$ & $87,56(-)$ & 0,250 & 0,500 \\
\hline Threonin & $4,0(68,00)$ & $67,18(-)$ & 0,108 & 0,215 \\
\hline Tirosin & - & $50,75(+)$ & 0,100 & 0,201 \\
\hline Valin & $0,4(6,80)$ & $86,82(+)$ & 0,185 & 0,370 \\
\hline
\end{tabular}

Sumber : * Ogino (1985) dalam Watanabe (1988)

**Berdasarkan hasil analisis laboratorium di PT. Saraswanti Indo Genetech

Keterangan : $1 \mathrm{ml}$ setara dengan $0,9 \mathrm{mg}$

(+) Kebutuhan asam amino ikan sidat terpenuhi

(-) Kebutuhan asam amino ikan sidat tidak terpenuhi

\section{Pembahasan}

\section{Laju pertumbuhan spesifik}

Hasil penelitian menunjukkan bahwa laju pertumbuhan spesifik tidak berbeda nyata pada berbagai perlakuan yang berarti penambahan asam amino dari ekstrak ikan pari tidak berpengaruh terhadap laju pertumbuhan spesifik ikan sidat. Hal ini disebabkan kandungan asam amino yang terdapat dalam pakan uji sebelum ditambahkan asam amino dari ekstrak ikan pari sudah cukup tinggi dibandingkan kandungan asam amino yang berasal dari ekstrak ikan pari dan beberapa diantaranya sudah memenuhi kebutuhan ikan sidat (Tabel 4). Penambahan asam amino dari ekstrak ikan pari masih belum mampu memenuhi kebutuhan ikan sidat yang tidak terpenuhi. Oleh karena itu, pakan yang digunakan tidak berpengaruh terhadap laju pertumbuhan ikan sidat.

Ikan membutuhkan komposisi yang seimbang antara asam amino esensial dan non esensial dalam menunjang pertumbuhan untuk mencukupi pertumbuhannya. Komposisi asam amino yang seimbang dalam pakan dengan komposisi asam amino yang terdapat dalam tubuh ikan akan menyebabkan ikan dapat tumbuh dengan normal (Buwono, 2000).

Beberapa penelitian menyebutkan bahwa ikan sidat $A$. 
bicolor ukuran $10 \mathrm{~g}$ yang diberi penambahan minyak ikan $5 \%$ dengan kandungan protein $43 \%$ memperoleh nilai laju pertumbuhan terbaik yaitu 1,36\% (Mukti, 2014). Chilmawati (2016) menyatakan bahwa ikan sidat A. bicolor dengan ukuran $15 \mathrm{~g}$ yang diberi penambahan tepung cacing tanah hasil fermentasi pada pakan pasta dengan kandungan protein $63 \%$ memperoleh nilai laju pertumbuhan terbaik $1,3 \%$. Hasil penelitian menunjukkan bahwa kandungan protein yang relatif sama antara perlakuan menghasilkan nilai laju pertumbuhan spesifik yaitu 5,39\% yang berarti penambahan asam amino pada pakan telah mencukupi kebutuhan pertumbuhan ikan sidat $A$. bicolor pada semua perlakuan.

\section{Jumlah konsumsi pakan dan efesiensi pakan}

Hasil penelitian menunjukkan bahwa jumlah konsumsi pakan dan efesiensi pakan tidak berbeda nyata pada berbagai perlakuan. Hal ini diduga bentuk/tekstur pada pakan tidak sesuai dengan ikan sidat. Menurut Safitri, (2014) pakan dengan bentuk pasta umum digunakan pada masa pemeliharaan ikan sidat, hal tersebut dilakukan agar ikan sidat dapat lebih mudah mencerna pakan yang diberikan. Matsui (1986) dalam Koroh (2014) menambahkan, pakan yang baik bagi ikan sidat adalah pakan daging segar yang berasal dari ikan, crustacea, dan kerang. Sedangkan pakan yang diberikan pada benih ikan sidat atau hasil budidaya yaitu berbentuk pasta.

Penurunan jumlah konsumsi pakan dipengaruhi oleh nafsu makan ikan tersebut. Sesuai dengan pernyataan Perwito (2015) yaitu apabila nafsu makan ikan berkurang maka jumlah pakan yang dikonsumsi akan berkurang sehingga pertumbuhan menjadi rendah. Faktor lainnya yang dapat mempengaruhi penuruan nafsu makan ikan yaitu kesehatan ikan.

Nilai efisiensi pakan berkaitan dengan laju pertumbuhan, dimana pada penelitian ini nilai efisiensi pakan berbanding lurus dengan nilai laju pertumbuhan. Hal ini dikarenakan semakin tinggi laju pertumbuhan maka semakin besar pertambahan berat tubuh ikan dan semakin besar nilai efesiensi pakan. Sesuai dengan pernyataan Djajasewaka (1985) bahwa nilai efesiensi pakan berbanding lurus dengan pertambahan berat tubuh ikan. Tingginya efisiensi pakan menunjukkan penggunaan pakan yang lebih efesien untuk pertumbuhan (NRC,1983).

\section{Retensi protein}

Hasil penelitian menunjukkan bahwa retensi protein ikan sidat tidak berbeda nyata pada berbagai perlakuan yang berarti kandungan asam amino dari ekstrak ikan pari belum mencukupi kebutuhan asam amino ikan sidat sehingga tidak dapat meningkatkan laju pertumbuhannya. Hal ini diduga karena protein yang telah diserap, terlebih dahulu dimanfaatkan oleh ikan sidat untuk aktivitas fisik, metabolisme dan kebutuhan pemeliharaan (maintenance). Kemudian jika berlebih akan disimpan atau diretensi dalam tubuh untuk membangun jaringan protein tubuh (dimanfaatkan bagi pertumbuhan).

Beberapa penelitian menyebutkan bahwa benih ikan sidat 
A. bicolor pada ukuran $1,5 \mathrm{~g}$ yang diberi pakan tanpa penambahan atraktan memperoleh nilai retensi protein tertinggi yaitu $12,83 \%$ dengan kandungan protein $50 \%$ (Yudiarto, 2012). Mukti (2014) menambahkan ikan sidat $A$. bicolor dengan ukuran $10 \mathrm{~g}$ yang diberi pakan dengan penambahan minyak ikan $5 \%$ memperoleh nilai retensi protein terbaik 20,24\% pada kandungan protein $43 \%$. Hasil penelitian menunjukkan bahwa kandungan protein $32 \%$ yang lebih rendah dengan ukuran ikan sidat $28 \mathrm{~g}$ yang lebih besar memperoleh nilai retensi protein yang lebih baik yaitu $27,92 \%$ yang berarti penambahan asam amino pada pakan telah mencukupi kebutuhan pertumbuhan ikan sidat $A$. bicolor pada semua perlakuan.

\section{Tingkat kelangsungan hidup}

Berdasarkan hasil uji statistik pada selang kepercayaan 95\% menunjukan bahwa antara perlakuan $\mathrm{A}, \mathrm{B}$, dan $\mathrm{C}$ menunjukkan hasil yang tidak berbeda nyata.Perlakuan A mengalami tingkat kematian yang cukup tinggi dibanding dengan perlakuan yang diperkaya dengan asam amino yang berasal dari ekstrak ikan pari. Hal ini disebabkan oleh faktor lingkungan yang tidak stabil karena keterbatasan peralatan yang ada untuk menunjang kelangsungan hidup ikan sidat. Menurut Fajar (1988) dalam Sukroso (2002) menyatakan bahwa tingkat kelangsungan hidup ikan dipengaruhi oleh manajemen budidaya yang baik antara lain padat tebar, kualitas pakan, kualitas air, dan parasit. Dengan penambahan asam amino, tingkat kelulushidupan pada ikan sidat lebih baik dari perlakuan kontrol. Hal ini sesuai dengan pernyataan Setiani (2004) yaitu keseimbangan komponen asam amino dalam pakan merupakan faktor utama dalam mempengaruhi pertumbuhan dan kesehatan ikan. Pakan buatan dari berbagai macam bahan baku pakan merupakan sumber nutrisi dalam akuakultur. Penyiapan pakan tidak hanya nutrisi yang dibutuhkan pada ikan, tetapi juga media dan komponen lain dapat mempengaruhi kesehatan ikan.

\section{Kualitas air}

Pengukuran kualitas air meliputi suhu, pH dan DO. Hasil pengukuran kualitas air dapat dilihat pada Tabel 3. Kualitas air selama pemeliharaan masih dapat tergolong optimal untuk pertumbuhan ikan sidat. Suhu air selama penelitian dari masing-masing perlakuan berkisar antara $25-26^{\circ} \mathrm{C}$. Kisaran suhu ini sudah memenuhi standar untuk pemeliharaan ikan sidat. Hal ini sesuai dengan pernyataan Sholeh (2004), bahwa ikan sidat lebih cepat tumbuh pada daerah yang bersuhu tinggi. Suhu yang cocok untuk pertumbuhan ikan sidat yaitu 23 $30^{\circ} \mathrm{C}$ dan pemeliharan ikan sidat harus memiliki pH berkisar antara 6,5 - 8,0. Berdasarkan penelitian yang telah dilakukan diperoleh nilai $\mathrm{pH}$ yaitu 6. Nilai $\mathrm{pH}$ yang terlalu rendah dapat menyebabkan nafsu makan ikan menurun. Hal ini disebabkan aktivitas dan produksi enzim pencernaan menjadi rendah serta terjadi penggumpalan lendir pada insang dan menimbulkan kematian karena kesulitan untuk mendapatkan oksigen (Riana, 2016). Kadar oksigen terlarut (DO) pada media pemeliharaan berkisar antara $5-6 \mathrm{mg} / \mathrm{l}$. Nilai 
tersebut masih dalam kondisi optimal untuk pertumbuhan ikan sidat. Sholeh (2004) menyatakan bahwa kisaran oksigen yang dapat menunjang pertumbuhan ikan sidat adalah $1-10$ $\mathrm{mg} / \mathrm{l}$.

\section{Kesimpulan}

Penambahan asam amino dari ekstrak ikan pari dengan dosis yang digunakan pada pakan belum mampu meningkatkan laju pertumbuhan ikan sidat.

\section{Daftar Pustaka}

Abdel-Tawwab, M., Ahmad, M., Khattab, Y.A.E., \& Shalaby, A.D.E. (2010). Effect of dietary protein level, initial body weight, and their interaction on the growth, feed utilization, and physiological alterations of nile tilapia, Oreochromis niloticus. Aquaculture, 298, 267 - 274.

Affandi R. 2005. Strategi Pemanfaatan Sumberdaya Ikan Sidat Anguilla spp. DiIndonesia. Jurnal Iktiologi Indonesia, 5(2): $77-81$.

Buwono, I.D. 2000. Kebutuhan Asam Amino Essensial Dalam Ransum Ikan. Buku Seri Perikanan. Penerbit Kanisius, Yogyakarta.

Cheng, W, Lai, C.S, \& Lin, Y.H. 2013. Quantifying the dietary protein and lipidrequirements of marble eel Anguilla marmorata with different body weight. Journal of The Fisheries Society of Taiwan 40: 135 - 142.

Chilmawati, D. 2016. Peningkatan produksi biomassa sidat (Anguilla bicolor) melalui pemanfaatan fermentasi pakan dan tepung cacing tanah (Lumbricus sp.). Journal of fisheris science and technology: $86-92$

Djajasewaka, H. \& Djajadireja, R. 1985. Pengaruh Makanan Buatan Dengan Kandungan Serat Kasar Berbeda terhadap Pertumbuhan Ikan Mas. Buletin Penelitian Perikanan Bogor, (I): 55 - 57.

Fajar, M. 1988. Budidaya Perairan Intensif. Universitas Brawijaya, Malang.

Kaushik, S.J, \& Seiliez, I. 2010. Protein and amino acid nutrition and metabolism in fish: Current knowledge and future needs. Aquaculture Research, 41: 322 332.

Koroh, P.A., \& Lumenta, C. 2014.Pakan Suspensi Daging Kekerangan bagi Pertumbuhan Benih Sidat (Anguilla bicolor). Jurnal Budidaya Perairan, 2(1): 7 $-13$.

Mardiah, Sawarni, H., Ashadi, R.W., \& Rahayu, A. 2009. Budi Daya dan Pengolahan Rosela si Merah Segudang Manfaat. Cetakan 1. Agromedia Pustaka, Jakarta.

Mukti, R.C, Utomo, N.B.P, \& Affandi, R. 2014. Penambahan minyak ikan pada pakan terhadap kinerja pertumbuhan dan komposisi asam lemak ikan sidat Anguilla bicolor bicolor. Jurnal Akuakutur Indonesia, 13(1): 54 60.

NRC [National Research Council]. 2011.Nutrient requirement of fish and shrimp. National Academic Press, Washington DC. $392 \mathrm{hlm}$.

Perwito, B., Hastuti, S., \& Yuniarti, T. 2015. Pengaruh Lama Waktu Perendaman Recombinant Growth Hormone $\quad(\mathrm{rGH})$ terhadap 
Pertumbuhan dan Kelulushidupan Larva Nil Salin (Oreochromis niloticus). Journal of Aquaculture Management and Technology, 4(4); $117-126$

Riana, H. 2016. Evaluasi nilai nutrisi tepung daun lamtoro gung (Leucaena leucocephala) yang difermentasi dengan cairan rumen kambing terhadap performa ikan gurami (Osphronemus gourami). Skripsi. Program Studi Budidaya Perairan, Fakultas Pertanian, Universitas Lampung, Bandar Lampung.

Rolis,2013. Pengaruh Pemberian Kombinasi Tepung Daging Keong Mas (Pomaecea canaliculata) dan Tepung Ikan terhadap Pertumbuhan Ikan Patin (Pangasius pangasius). Skripsi. Program Studi Pendidikan Biologi, Fakultas Keguruan dan Ilmu Pendidikan, Universitas Muhammadiyah Purwokerto, Purwokerto

Safitri, A. 2014. Kinerja Pertumbuhan Ikan Sidat Anguilla bicolor Stadia Yellow Eel Yang Diberi Pakan
Pasta Dengan Sumber Protein Berbeda. Skripsi. Departemen Budidaya Perairan, Institut Pertanian Bogor, Bogor

Sholeh, S.A. 2004. Peranan Jumlah Shelteryang Berbeda Terhadap /ertumbuhan dan Kelangsungan Hidup Benih Ikan Sidat (Anguilla sp.). Skripsi. Teknologi dan Manajemen Akuakultur, Departemen Budidaya Perairan, Fakultas Perikanan dan Ilmu Kelautan, Institut Pertanian Bogor, Bogor.

Watanabe, T. 1988. Fish Nutrition and Mariculture. JICA. The General Aquaculture Course. Dept of Agriculture Bioscience, Tokyo University, Japan. $233 \mathrm{hlm}$.

Yudiarto, S., Arief, M., dan Agustono. 2012. Pengaruh penambahan atraktan yang berbeda dalam pakan pasta terhadap retensi protein, lemak dan energi benih ikan sidat (Anguilla bicolor) stadia elver. Jurnal Ilmiah Perikanan dan Kelautan, 4(2): 135 $-140$. 
